\title{
The Osmotic Responses of Penicillium ochro-chloron: Changes in Internal Solute Levels in Response to Copper and Salt Stress
}

\author{
By G. M. GADD,$^{1 *}$ J. A. CHUDEK, ${ }^{2}$ R. FOSTER ${ }^{2}$ AND R. H. REED ${ }^{1}$ \\ ${ }^{1}$ Department of Biological Sciences and ${ }^{2}$ Department of Chemistry, University of Dundee, \\ Dundee DDI $4 H N, U K$
}

(Received 6 February 1984; revised 9 April 1984)

\begin{abstract}
The marked copper tolerance of Penicillium ochro-chloron has been confirmed as has its ability to grow in solutions of high salinity. The major low molecular weight organic solutes present in $P$. ochro-chloron were glycerol, erythritol, arabitol, mannitol, sorbitol and trehalose. Of these, glycerol increased significantly during growth in high concentrations of $\mathrm{Na}^{+}$or $\mathrm{Cu}^{2+}$, a 15-fold increase, relative to the control, occurring in concentrations of $0.5 \mathrm{M}$. Cell $\mathrm{K}^{+}$increased with elevated external $\mathrm{Na}^{+}$but decreased slightly with elevated external $\mathrm{Cu}^{2+}$. With high external $\mathrm{Cu}^{2+}$ mycelium maintained a constant level of $\mathrm{Cu}^{2+}$, with low levels of $\mathrm{Na}^{+}$in all treatments. It is concluded that the high concentrations of glycerol induced by high external $\mathrm{Na}^{+}$or $\mathrm{Cu}^{2+}$ had a significant osmotic effect, allowing growth in media of high osmolality. The exclusion of ions may have a gratuitous role in the copper tolerance of $P$. ochro-chloron.
\end{abstract}

\section{INTRODUCTION}

Above micronutrient levels, the fungicidal nature of copper compounds is commonly assumed, but certain fungi have the ability to withstand and grow in concentrations that are toxic to most other organisms (see Ross, 1975; Gadd \& Griffiths, 1978). Penicillium ochro-chloron has been the subject of a number of studies because of its extreme tolerance to copper and certain other metals. It has a high copper requirement for optimal growth and sporulation (Basu et al., 1955) and can grow in copper sulphate concentrations up to saturation (Okamoto \& Fuwa, 1974; Okamoto et al., 1977). There are widely differing values reported for copper accumulation by this organism (Basu et al., 1955; Okamoto \& Fuwa, 1974; Stokes \& Lindsay, 1979; Baldry \& Dean, 1980), but, as yet, there is no detailed information on the physiology of heavy metal tolerance. Resistance mechanisms found in some other fungi, such as sulphide or oxalate production or intracellular localization (see Ross, 1975; Gadd \& Griffiths, 1978; Murphy \& Levy, 1983), have not been demonstrated in P. ochro-chloron.

Copper sulphate solutions are acidic and while low pH values are effective in moderating copper toxicity to Scytalidium sp. (Starkey, 1973) and Aureobasidium pullulans (Gadd \& Griffiths, 1980), for $P$. ochro-chloron there is little difference in the effects of copper on growth from $\mathrm{pH} 2.0$ to $\mathrm{pH}$ 6.0 (Stokes \& Lindsay, 1979).

Fungi growing in solutions of high osmolality often accumulate one or more intracellular solutes that have an 'osmoregulatory' function (see Jennings, 1983). Since a considerable osmotic potential is generated by high copper sulphate concentrations $\left(1 \cdot 129 \mathrm{M}-\mathrm{CuSO}_{4} \equiv\right.$ $0.523 \mathrm{M}-\mathrm{NaCl} \equiv$ sea water $\equiv 1.050$ osmol kg-1), the intracellular solute content of $P$. ochrochloron was investigated over a range of external copper concentrations to establish the role, if any, of such solutes in heavy metal tolerance. Growth and intracellular solute concentrations have also been studied in response to $\mathrm{NaCl}$ stress to determine whether similar osmotic responses are initiated by $\mathrm{NaCl}$ and $\mathrm{CuSO}_{4}$.

Natural abundance ${ }^{13} \mathrm{C}$ nuclear magnetic resonance spectrometry (NMR) was used to identify the major low molecular weight organic solutes in $P$. ochro-chloron. This technique 
allows unequivocal identification and, where these organic solutes are present in osmotically significant amounts, the ${ }^{13} \mathrm{C}$ resonances from such compounds can be identified in a relatively short time (Borowitzka et al., 1980; Reed et al., 1984). Intracellular accumulation of low molecular weight organic solutes (quantified by gas-liquid chromatography) was coupled to measurements of the principal inorganic ions to assess the osmotic significance of inorganic and organic solutes in P. ochro-chloron.

\section{METHODS}

Organism, media and growth conditions. Penicillium ochro-chloron (IMI 39806) was routinely maintained on 4.7\% (w v) malt agar (Lab M. Ford Lane, Salford, UK). The liquid medium used was of composition ( $\mathrm{g} \mathrm{l}^{-1}$ ): D-glucose, $20.0 ;\left(\mathrm{NH}_{4}\right)_{2} \mathrm{SO}_{4}, 5 \cdot 0 ; \mathrm{KH}_{2} \mathrm{PO}_{4}, 0 \cdot 5 ; \mathrm{MgSO}_{4} .7 \mathrm{H}_{2} \mathrm{O}, 0 \cdot 2 ; \mathrm{CaCl}_{2} .6 \mathrm{H}_{2} \mathrm{O}, 0.05 ; \mathrm{NaCl}, 0 \cdot 1 ; \mathrm{FeCl}_{3} .6 \mathrm{H}_{2} \mathrm{O}, 0.0025$; $\mathrm{ZnSO}_{4} \cdot 7 \mathrm{H}_{2} \mathrm{O}, 0.004 ; \mathrm{MnSO}_{4} \cdot 4 \mathrm{H}_{2} \mathrm{O}, 0.004 ; \mathrm{CuSO}_{4} .5 \mathrm{H}_{2} \mathrm{O} .0 .0004$. Starter cultures were prepared by inoculating $50 \mathrm{ml}$ culture medium with several $6 \mathrm{~mm}$ diameter discs excised from actively growing colonies on malt agar and incubating for $24-28 \mathrm{~h}$ on an orbital shaker $\left(100\right.$ cycles $\left.\mathrm{min}^{-1}\right)$. These were used, after one further subculture, to inoculate aspirators containing 1 litre medium to an initial density of approximately $0.04 \mathrm{mg} \mathrm{dry} \mathrm{wt} \mathrm{ml}^{-1}$. Required amounts of crystals of $\mathrm{CuSO}_{4}$ or $\mathrm{NaCl}$ (sterilized at $160^{\circ} \mathrm{C}$ for at least $3 \mathrm{~h}$ ) were added to the aspirators after sterilization. All cultures were incubated at $23{ }^{\circ} \mathrm{C}$ with stirring and forced aeration.

${ }^{13} \mathrm{C}$ NMR. Natural abundance ${ }^{13} \mathrm{C}\left\{{ }^{1} \mathrm{H}\right\}$ NMR spectra were measured using a Bruker WP60 FT spectrometer operating at $15.08 \mathrm{MHz}$. $\mathrm{D}_{2} \mathrm{O}(10 \%)$ was added to each sample to provide a lock signal and methanol [49.0 p.p.m. downfield from 3-(trimethylsilyl)-1-propanesulphonic acid] was used as an internal standard. Spectra were obtained using a $7 \mu$ s pulse $\left(65^{\circ}\right)$ and a recycle time of $1.1 \mathrm{~s}$. A total of 1500 scans was accumulated for each sample; these were transformed after exponential broadening of $1.5 \mathrm{~Hz}$. Concentrated extracts of 2-week-old mycelium were obtained by extraction in $80 \%(\mathrm{v} / \mathrm{v})$ ethanol overnight, and were assayed at $30^{\circ} \mathrm{C}$ in $10 \mathrm{~mm}$ o.d. tubes.

Gas-liquid chromatography. GLC separation of the major low molecular weight, alcohol-soluble organic solutes was carried out on trimethylsilyl-derivatized samples, following extraction in $80 \%$ ( $\left.v_{i}^{\prime} v\right)$ ethanol, rotary evaporation and storage in a vacuum desiccator for $48 \mathrm{~h}$ (Holligan \& Drew, 1971). Samples were assayed in pyridine using a Varian 3700 chromatograph and Hewlett Packard 3390A integrator, with the temperature programmed from $90^{\circ} \mathrm{C}$ to $280^{\circ} \mathrm{C}$ at $20^{\circ} \mathrm{C} \mathrm{min}^{-1}$, holding the initial and final temperatures for $1 \mathrm{~min}$. All other conditions were as previously described (Reed et al., 1980; Reed \& Stewart, 1983).

Metal analysis. Samples $(10 \mathrm{ml})$ of mycelial suspensions were harvested in the stationary phase after $12-14 \mathrm{~d}$ growth by vacuum filtration onto Whatman GF/C glass microfibre papers $(5.5 \mathrm{~cm}$ diameter), rinsed with distilled water and then washed twice with $0.5 \mathrm{M}-\mathrm{CaCl}_{2}$, to remove loosely associated extracellular ions, at $4{ }^{\circ} \mathrm{C}$. Mycelial mats were easily removed from the filter papers by peeling and placed in clean polypropylene tubes. For ion extraction, $2.0 \mathrm{ml} 6 \mathrm{M}-\mathrm{HNO}_{3}$ was added to the pellets, which were then kept at $90^{\circ} \mathrm{C}$ for $2 \mathrm{~h}$. Distilled water $(8.0 \mathrm{ml})$ was then added and the extracts were left to settle overnight. Ion concentrations in these supernatants and reagent controls were determined using a Pye Unicam SP9 atomic absorption spectrophotometer after appropriate dilution.

Other methods. Dry weights were determined using tared aluminium foil cups dried to constant weight at $105^{\circ} \mathrm{C}$. Intracellular water content was measured as: total fresh wt - dry wt - extracellular water content. Here, dry weights were measured after drying to constant weight at $65^{\circ} \mathrm{C}$ for $7 \mathrm{~d}$. Extracellular water contents were assayed by short-term incubation $(120 \mathrm{~s})$ in $\left[{ }^{1+} \mathrm{C}\right]$ sorbitol $\left(10 \mathrm{mM}\right.$; specific activity $\left.2 \mathrm{GBq} \mathrm{mol}^{-1}\right)$, as described by Reed (1980).

\section{RESULTS}

Natural abundance ${ }^{13} \mathrm{C}$ NMR spectroscopy revealed the major low molecular weight organic solutes present in P. ochro-chloron and representative traces are shown in Fig. 1. The traces, as shown, give no quantitative data, although the relative importance of the principal organic solutes can be seen by studying the lines corresponding to each compound, in relation to each other. The spectra are more complex than previously published spectra for cyanobacteria (Borowitzka et al., 1980; Mackay et al., 1983: Reed et al., 1984), due to the presence of several low molecular weight organic solutes (see Hocking \& Norton, 1983), namely glycerol $(\delta 63.8[\mathrm{C}$ $1 / \mathrm{C}-3]$ and $73 \cdot 2[\mathrm{C}-2])$, erythritol $(\delta 63 \cdot 8[\mathrm{C}-1 / \mathrm{C}-4]$ and $73 \cdot 2[\mathrm{C}-2 / \mathrm{C}-3])$, arabitol $(\delta 64 \cdot 2[\mathrm{C}-1 / \mathrm{C}-5]$, $71 \cdot 4[\mathrm{C}-2 / \mathrm{C}-3]$ and $72 \cdot 2[\mathrm{C}-4])$, mannitol $(\delta 64 \cdot 6[\mathrm{C}-1 / \mathrm{C}-6], 72 \cdot 2[\mathrm{C}-2 / \mathrm{C}-5]$ and $70 \cdot 7[\mathrm{C}-3 / \mathrm{C}-4])$, sorbitol $(\delta-63 \cdot 7[\mathrm{C}-1], 72 \cdot 3[\mathrm{C}-2 / \mathrm{C}-4], 71 \cdot 0[\mathrm{C}-3], 74 \cdot 2[\mathrm{C}-5]$ and $64 \cdot 1[\mathrm{C}-6])$ and trehalose $(\delta 94 \cdot 5$ $[\mathrm{C}-1], 73 \cdot 6[\mathrm{C}-2 / \mathrm{C}-3], 70 \cdot 8[\mathrm{C}-4], 72 \cdot 3[\mathrm{C}-5]$ and $61.9[\mathrm{C}-6])$. Since the resonances are often 


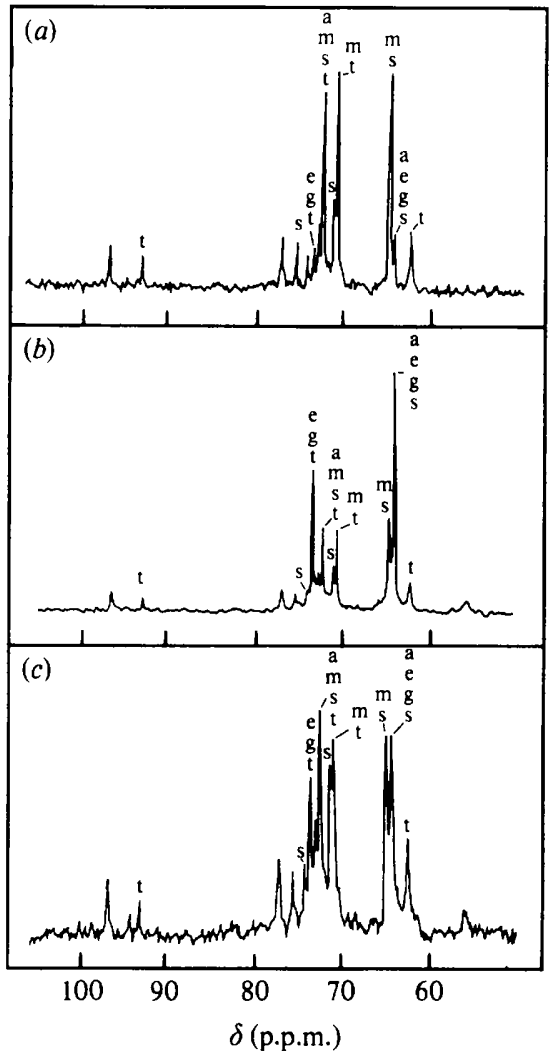

Fig. $1 .{ }^{13} \mathrm{C}$ NMR spectra of mycelial extracts of $P$.ochro-chloron. (a) Control; (b) $0.5 \mathrm{M}-\mathrm{NaCl} ;(c) 0.5 \mathrm{M}$ $\mathrm{CuSO}_{4}$. The peaks are labelled as follows : a, arabitol ; e, erythritol; g, glycerol; m, mannitol; s, sorbitol; t, trehalose.

superimposed, interpretation of the traces is complex, although most compounds have at least one unique resonance by which they can be identified (Fig. 1). Unidentified, smaller resonances were also observed at $\delta 76.4,77 \cdot 7$ and $98 \cdot 1$.

The control sample shows strong ${ }^{13} \mathrm{C}$ resonances corresponding to the spectrum of mannitol, with smaller resonances for all other compounds. Cells grown in $0.5 \mathrm{M}-\mathrm{NaCl}$ show enhanced resonances at $\delta 63.8$ and 73.2 , due to glycerol/erythritol. In contrast, cells grown in $0.5 \mathrm{M}-\mathrm{CuSO}_{4}$ show mannitol and glycerol/erythritol resonances of comparable magnitude. Little evidence of change in the other compounds was evident from the results in Fig. 1.

Cell water and amounts of osmotically-important intracellular solutes in $P$. ochro-chloron, after growth in various $\mathrm{Na}^{+}$or $\mathrm{Cu}^{2+}$ concentrations, are shown in Table 1. The same compounds, as qualitatively determined by ${ }^{13} \mathrm{C}$ NMR, were also identified by GLC but this latter method enabled quantification. However, GLC does not discriminate between trimethylsilyl derivatives of mannitol and sorbitol (Holligan \& Drew, 1971), so the values in Table 1 are termed 'hexitol', but mannitol will predominate as it is found in substantially greater amounts than sorbitol (Fig. 1). On a dry weight basis, glycerol, erythritol and trehalose all showed increases (arabitol only in $\mathrm{Na}^{+}$) with higher ionic concentration whereas 'hexitol' concentrations were approximately constant. Glycerol showed the greatest relative increase with values 7.8 and 8.7 times greater than the control for $0.5 \mathrm{M}-\mathrm{Cu}^{2+}$ and $\mathrm{Na}^{+}$, respectively. When account was taken of cell water, which showed a general decrease to about $55 \%$ of the control value at $0.5 \mathrm{M}-\mathrm{Na}^{+}$or $\mathrm{Cu}^{2+}$ (Table 1), glycerol concentrations showed an approximately 15-fold increase relative to the control, for both $\mathrm{Cu}^{2+}$ and $\mathrm{Na}^{+}$at $0.5 \mathrm{M}$ (Fig. 2). Concentrations of the other low molecular weight organic compounds, in terms of cell water, can be calculated 
Table 1. Cell water and organic solute levels $( \pm \mathrm{SE})$ in P. ochro-chloron after 2 weeks growth in various concentrations of $\mathrm{NaCl}$ or $\mathrm{CuSO}_{4}$

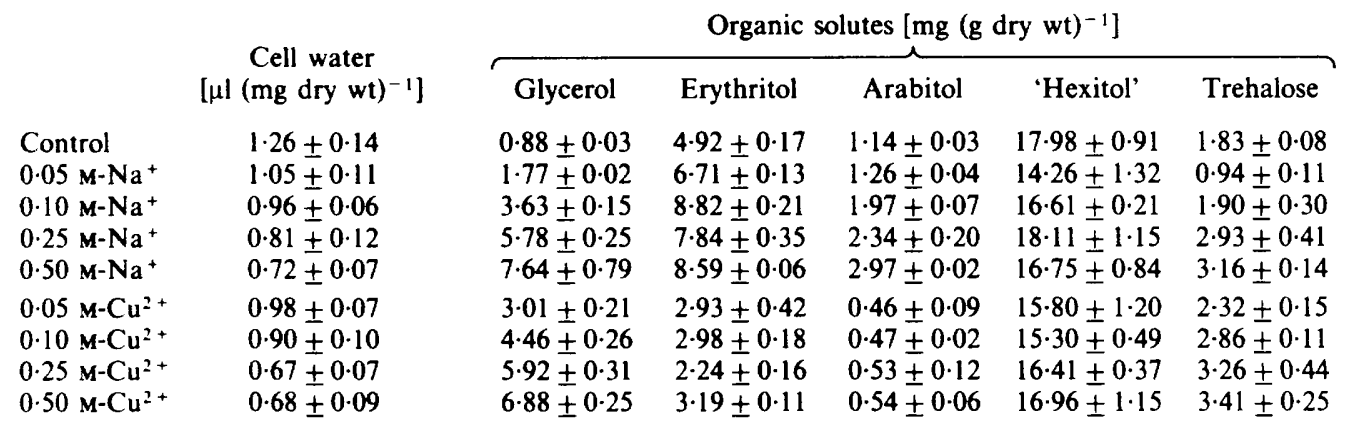

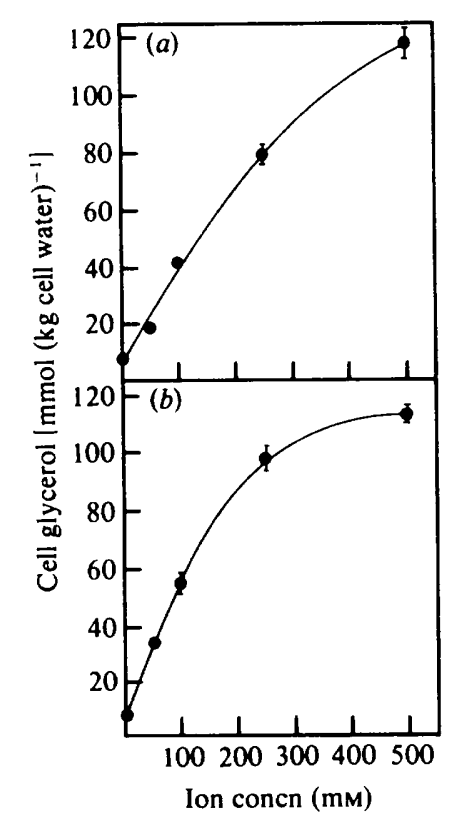

Fig. 2. Glycerol concentrations in 2-week-old mycelium of $P$. ochro-chloron grown in various concentrations of $(a) \mathrm{NaCl}$ and $(b) \mathrm{CuSO}_{4}$. Bars indicate sE.

from the data in Table 1 but none increased as much as glycerol and only 'hexitol' ( 1.6 times the relative increase over the control) was present at concentrations similar to or slightly greater than those for glycerol in both $\mathrm{Cu}^{2+}$ and $\mathrm{Na}^{+}$.

Mycelial yields and cellular levels of $\mathrm{Cu}^{2+}, \mathrm{K}^{+}$and $\mathrm{Na}^{+}$, on a dry weight basis, are shown in Table 2. There was a decrease in biomass with increasing $\mathrm{Na}^{+}$, an approximately $50 \%$ reduction occurring in $0.5 \mathrm{M}-\mathrm{NaCl}$, but in copper the decrease was not so marked, with only a $20 \%$ reduction at $0.5 \mathrm{M}-\mathrm{CuSO}_{4}$. There was some increase in cell $\mathrm{K}^{+}$at 0.1 and $0.5 \mathrm{M}-\mathrm{NaCl}$, but in the presence of copper there was a uniform decrease to about $74 \%$ of the control $\mathrm{K}^{+}$level at all concentrations used. Cell $\mathrm{Cu}^{2+}$ was low in control cells and there was no significant difference between values obtained for cells grown in 0.25 and $0.5 \mathrm{M}-\mathrm{CuSO}_{4} \cdot \mathrm{Na}^{+}$was low in all samples although there was some increase with higher external $\mathrm{NaCl}$ concentrations. Calculated intracellular osmolalities, assuming $\mathrm{Cl}^{-}$acts as the counterion to all cations present, were generally equivalent to the extracellular osmolality at all but the highest concentrations of $\mathrm{Na}^{+}$ and $\mathrm{Cu}^{2+}$ (Table 3). 
Table 2. Mycelial yields and levels of $\mathrm{K}^{+}, \mathrm{Cu}^{2+}$ and $\mathrm{Na}^{+}( \pm \mathrm{SE})$ in P. ochro-chloron after 2 weeks growth in various concentrations of $\mathrm{NaCl}$ or $\mathrm{CuSO}_{4}$

\begin{tabular}{|c|c|c|c|c|}
\hline & \multirow{2}{*}{$\begin{array}{c}\text { Mycelium } \\
\left.\text { (mg dry wt } \mathrm{ml}^{-1}\right)\end{array}$} & \multicolumn{3}{|c|}{ Concn [nmol (mg dry wt $)^{-1}$ ] } \\
\hline & & Cell $\mathbf{K}^{+}$ & Cell $\mathrm{Cu}^{2+}$ & Cell $\mathrm{Na}^{+}$ \\
\hline $\begin{array}{l}\text { Control } \\
0 \cdot 10 \mathrm{M}-\mathrm{Na}^{+} \\
0.25 \mathrm{M}-\mathrm{Na}^{+} \\
0.50 \mathrm{M}-\mathrm{Na}^{+}\end{array}$ & $\begin{array}{l}8.73 \pm 0.84 \\
6.83 \pm 0.48 \\
5.83 \pm 0.52 \\
4.27 \pm 0.39\end{array}$ & $\begin{array}{l}62.64 \pm 2.59 \\
71.28 \pm 2.38 \\
60.38 \pm 1.51 \\
97.66 \pm 1.02\end{array}$ & $\begin{array}{c}0.33 \pm 0.09 \\
\text { ND } \\
\text { ND } \\
\text { ND }\end{array}$ & $\begin{array}{l}2.40 \pm 0.10 \\
3.28 \pm 0.82 \\
4.78 \pm 0.76 \\
6.51 \pm 0.69\end{array}$ \\
\hline $\begin{array}{l}0.10 \mathrm{M}-\mathrm{Cu}^{2+} \\
0.25 \mathrm{M}-\mathrm{Cu}^{2+} \\
0.50 \mathrm{M}-\mathrm{Cu}^{2+}\end{array}$ & $\begin{array}{l}8.44 \pm 0.23 \\
7.73 \pm 0.59 \\
6.73 \pm 0.50\end{array}$ & $\begin{array}{l}45.14 \pm 3.02 \\
46.02 \pm 0.87 \\
47.50 \pm 0.86\end{array}$ & $\begin{array}{r}4.80 \pm 0.70 \\
23 \cdot 20 \pm 2.54 \\
25 \cdot 37 \pm 1 \cdot 36\end{array}$ & $\begin{array}{c}4.92 \pm 2 \cdot 10 \\
\mathrm{ND} \\
9 \cdot 24 \pm 3 \cdot 00\end{array}$ \\
\hline
\end{tabular}

ND, Not determined.

Table 3. Intra- and extracellular osmolalities of P. ochro-chloron after 2 weeks growth in various concentrations of $\mathrm{NaCl}$ or $\mathrm{CuSO}_{4}$

$\begin{array}{lcc}\text { Extracellular osmolality } & \text { Intracellular osmolality } \\ \text { [osmol (kg cell water) }\end{array}$

* Calculated from data in Tables 1 and 2, assuming $\mathrm{Cl}^{-}$acts as counterion.

\section{DISCUSSION}

In this study the marked copper tolerance of $P$. ochro-chloron has been confirmed as has its ability to grow in solutions of high salinity. Fungi that grow in saline conditions often accumulate one or more intracellular solutes, including polyols and/or low molecular weight saccharides, which help to maintain osmotic balance and generate the positive turgor pressures required for growth (see Jennings, 1983) and also confer protection against $\mathrm{NaCl}$ inactivation of enzymes (see Borowitzka \& Brown, 1974; Brown, 1983). The major compounds present in $P$. ochro-chloron were glycerol, mannitol, sorbitol, arabitol, erythritol and trehalose, with glycerol showing the greatest response to increasing external ionic concentration (equivalent to decreasing water activity). High induced glycerol concentrations, as a response to increased salinity, have been frequently reported for yeasts including Saccharomyces rouxii and $S$. cerevisiae, Debaromyces hansenii, Pichia miso and filamentous fungi including Dendryphiella salina, Penicillium chrysogenum and Chaetomium globosum (see Jennings, 1983). The ecology of $P$. ochro-chloron is poorly understood and there are, to our knowledge, no reports of its occurrence in marine habitats, but this glycerol-producing ability is not confined to marine or halotolerant fungi (Brown, 1978). Copper caused almost identical marked changes in glycerol concentrations within cells, which agrees with the hypothesis that glycerol production is a direct response to a decrease in water activity of the medium (Brown, 1976, 1978).

Sodium is toxic at high concentrations in marine fungi (Jones \& Byrne, 1976; Jennings, 1983); $P$. ochro-chloron contained very low amounts of sodium. The osmolality of $0.5 \mathrm{M}-\mathrm{NaCl}$ is approximately twice that of $0.5 \mathrm{M}-\mathrm{CuSO}_{4}$ (Table 3) yet glycerol concentrations were approximately equal in cells grown in equal concentrations of both solutes. However, the increases in $\mathrm{K}^{+}$and erythritol that occurred with higher external $\mathrm{NaCl}$ concentrations but not with copper (see Tables 1 and 2) may account for the apparent shortfall in intracellular glycerol concentration in $\mathrm{Na}^{+}$-containing medium. The uniform decrease in cell $\mathrm{K}^{+}$with 
increasing $\mathrm{Cu}^{2}+$ concentration may indicate some membrane disruption, but since there was only a slight decrease in yield at the highest $\mathrm{Cu}^{2+}$ concentration, this implies that $\mathrm{K}^{+}$release may have occurred to compensate for $\mathrm{Cu}^{2+}$ uptake. Stoichiometric release of $\mathrm{K}^{+}$in conjunction with heavy metal uptake is found in several yeasts and fungi at non-toxic concentrations (Norris \& Kelly, 1977; Mowll \& Gadd, 1984). However, when values are converted to unit cell water, by means of the data in Table 1 , the losses are generally insignificant. Changes in intracellular solute content are sufficient to balance the increases in extracellular osmolality at all but the highest concentrations of $\mathrm{Na}^{+}$and $\mathrm{Cu}^{2+}$. The apparent shortfall at the highest osmolalities, if experimental variation is insignificant, could be due to the presence of unidentified intracellular inorganic solutes.

Total cell copper values were low, especially in view of the high external concentrations, and the observation that a saturation value was reached implies some control of cellular uptake. This constant copper content has also been noted previously (Okamoto \& Fuwa, 1974; Okamoto et al. . 1977) with values of about $16 \mathrm{nmol} \mathrm{mg}^{-1}$ at copper concentrations from $16 \mathrm{~mm}$ up to saturation values. There is wide variation in other reported values, e.g. Baldry \& Dean (1980)

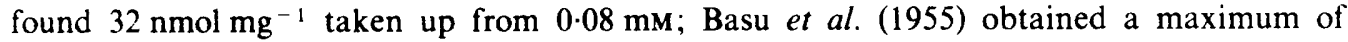
$630 \mathrm{nmol} \mathrm{mg}^{-1}$ from $50 \mathrm{~mm}$ and Stokes \& Lindsay (1979) obtained $6300 \mathrm{nmol} \mathrm{mg}{ }^{-1}$ after $1 \mathrm{~d}$ in solutions of 8,16 and $80 \mathrm{~mm}$ (figures calculated from cited references). While some variation may be due to strain and cultural differences, it is likely that inadequate washing of mycelium, always a problem with filamentous fungi, may have led to some of the higher estimations. There are few published values of copper accumulation for other filamentous fungi.

While low $\mathrm{pH}$ can reduce heavy metal toxicity to fungi by reducing uptake (Starkey, 1973; Gadd \& Griffiths, 1980) and may have had some contribution in this study, the huge excess of $\mathrm{Cu}^{2+}$ and $\mathrm{Na}^{+}$present still implies some cellular control of influx. From this study, we conclude that the high concentrations of cellular glycerol, induced by high $\mathrm{Cu}^{2+}$ and $\mathrm{Na}^{+}$, have a significant osmotic effect, allowing growth in media of high osmotic strength. The exclusion of $\mathrm{Cu}^{2}+$ may be considered as a gratuitous resistance mechanism (Gadd \& Griffiths, 1978) since it is not specific for copper and can also apply to sodium. However, such ion exclusion and intracellular osmotic compensation involving polyols is of clear ecological and physiological significance for organisms which grow in marine and/or low water activity habitats.

R. H. R. acknowledges support from the Royal Society.

\section{REFERENCES}

Baldry, M. G. C. \& Dean, A. C. R. (1980). Copper accumulation by bacteria, moulds and yeasts. Microbios 29, 7- 14 .

Bast, S. N., Bose, R. G. \& Bhattacharyya, J. P. (1955). Some physiological studies on a coppertolerant Penicillium species. Journal of Scientific and Industrial Research 14C, 46-53.

BorowitzKa, L. J. \& Brown, A. D. (1974). The salt relations of marine and halophilic species of the unicelluiar green alga Dunaliella. The role of glycerol as a compatible solute. Archives of Microbiology 96, $37-52$.

Borowitzka, L. J., Demmerle, S., Mackay, M. A. \& NoRTON, R. S. (1980). Carbon-13 nuclear magnetic resonance study of osmoregulation in a blue-green alga. Science 210, 650-651.

Brown, A. D. (1976). Microbial water stress. Bacteriological Reviews 40, 803-846.

Brown, A. D. (1978). Compatible solutes and extreme water stress in eukaryotic microorganisms. Adtances in Microbial Physiology 17, 181-242.

Brown, A. D. (1983). Halophilic prokaryotes. In Encyclopaedia of Plant Physiology 12C, pp. 137-162. Edited by O. L. Lange, P. S. Nobel, C. B. Osmond \& H. Ziegler. Berlin: Springer.
GadD, G. M. \& Griffiths, A. J. (1978). Microorganisms and heavy metal toxicity. Microbial Ecology 4, 303-317.

GADD, G. M. \& GRIfFITHS, A. J. (1980). Influence of $\mathrm{pH}$ on toxicity and uptake of copper in Aureobasidium pullulans. Transactions of the British Mycological Society 75, 91-96.

Hocking, A. D. \& Norton, R. S. (1983). Naturalabundance ${ }^{13} \mathrm{C}$ nuclear magnetic resonance studies on the internal solutes of xerophilic fungi. Journal of General Microbiology' 129, 2915-2925.

Holligan, P. M. \& Drew, E. A. (1971). Routine analysis by gas-liquid chromatography of soluble carbohydrates in extracts of plant tissues. II Quantitative analysis of standard carbohydrates and the separation and estimation of soluble sugars from a variety of plant tissues. New Phytologist 70, 270297.

JENNingS, D. H. (1983). Some aspects of the physiology and biochemistry of marine fungi. Biological Reviews 58, 423-459.

Jones, E. B. G. \& Byrne, P. J. (1976). Physiology of the higher marine fungi. In Recent Adiances in Aquatic Mycology, pp. 1-49. Edited by E. B. G Jones. London: Elek Science 
Mackay, M. A., Norton, R. S. \& Borowitzka, L. J. (1983). Marine blue-green algae have a unique osmoregulatory system. Marine Biology 73, 301-307.

Mowll, J. L. \& GADD, G. M. (1984). Cadmium uptake by Aureobasidium pullulans. Journal of General Microbiology 130, 279-284.

Murphy, R. J. \& Levy, J. F. (1983). Production of copper oxalate by some copper tolerant fungi. Transactions of the British Mycological Society 81, 165-168.

NorRis, P. R. \& Kelly, D. P. (1977). Accumulation of cadmium and cobalt by Saccharomyces cerevisiae. Journal of General Microbiology 99, 317-324.

Okamoto, K. \& Fuwa, K. (1974). Copper tolerance of a new strain of Penicillium ochro-chloron. Agricultural and Biological Chemistry 38, 1405-1406.

Okamoto, K., Suzuki, M., Fukami, M., Toda, S. \& FUWA, K. (1977). Uptake of heavy metals by a copper-tolerant fungus, Penicillium ochro-chloron. Agricultural and Biological Chemistry 41, 17-22.

REED, R. H. (1980). The influence of salinity upon cellular mannitol concentration of the euryhaline marine alga Pilayella littoralis (L.) Kjellm. (Phaeophyta, Ectocarpales): preliminary observations. Botanica Marina 23, 603-605.
Reed, R. H. \& Stewart, W. D. P. (1983). Physiological responses of Rivularia atra to salinity: osmotic adjustment in hyposaline media. New Phytologist 95 , 595-603.

ReEd, R. H., Collins, J. C. \& Russell, G. (1980). The effects of salinity upon galactosylglycerol content and concentration of the marine red alga Porphyra purpurea (Roth.) C. Ag. Journal of Experimental Botany 31, 1539-1554.

Reed, R. H., Chudek, J. A., Foster, R. \& Stewart, W. D. P. (1984). Osmotic adjustment in cyanobacteria from hypersaline environments. Archives of Microbiology (in the Press).

Ross, I. S. (1975). Some effects of heavy metals on fungal cells. Transactions of the British Mycological Society 64, 175-193.

STARKEY, R. L. (1973). Effect of pH on toxicity of copper to Scytalidium sp., a copper-tolerant fungus, and some other fungi. Journal of General Microbio$\log y$ 78, 217-225.

Srokes, P. M. \& Lindsay, J. E. (1979). Copper tolerance and accumulation in Penicillium ochrochloron isolated from copper-plating solution. Mycologia 71, 796-806. 